\title{
Brief Review of the Theory of Liquid Immiscibility of Kimberlite Magma
}

Kryvoshlyk, I.N.

SouthernEra Resources Ltd, 33 Yonge Street, Suite 1040, Toronto, Ontario, Canada M5E 1S9

This communication based on the long-time research of kimberlite pipes of Yakutia, Russia. First scientific report about this problem has been prepared in December 1973.

There are two main kimberlite rock varieties: massive kimberlite (Photo 1) and autolithic kimberlite (Photo 2) ( former kimberlite "tuff") can be determined.

The autoliths are the most important part of both kimberlites. Autolithic material composes about 50 $\%$ of autolithic kimberlite, and all $100 \%$ of massive kimberlite.

Fully developed autolith has spheroidal shape . In the centre, as a rule, the pseudomorphose after olivine or xenolith of wall rocks are situate. Some of autoliths have concentric-zoned texture (Photo $3,4)$. Autoliths, which consist of a small portion of kimberlite "tuff", surrounded by a cover (coat) of massive kimberlite have been found (Photo 5). Sometimes these autoliths have a burst (torn) cover of massive kimberlite, and their "tuff" core flow together with surrounding autolith "tuff" (Photo 6).

It is known (Ilupin, Kaminsky and Frantsesson, 1978), that kimberlites compare with other ultrabasic rocks abundant with titanium, potassium, phosphorus, boron, hydrogen and some other elementscatalysts of liquid immiscibility.

It is possible to suppose, that the kimberlite magma just before eruption passed through the moment of the liquid immiscibility, and generated two secondary melts: silicate ultrabasic, which gave autoliths, and non-silicate carbonatitic melt, which hardened as groundmass of autolithic kimberlite. In other words, the autolithic kimberlite is a mechanic mixture of both melts, which had no time for their spatial separation. Concentrated silicate melt gave autoliths, and concentrated carbonatitic melt gave a globules, which very often look like xenoliths of limestones or veins of postmagmatic carbonates.

During the process of liquid immiscibility the kimberlite magma spent lot of its inner energy for separation of the primary liquid for two new melts, and as result it has been deep over-cooled. The phenomenon of over-cooling of liquids due to their immiscibility confirmed by theoretic (Tamman, 1935) and experimental work (Anikin, 1977).

This is why around kimberlite pipes we see so weak signs of contact metamorphism. The overcooling crushed mantle diamonds and indicator minerals. It hindered graphitization of diamonds.

In over-cooling conditions the silicate melt became hard, and along with xenoliths could periodically obstruct the channel of eruption, and to generate the phenomenon of water-hammer.

During the repeating water-hammers the new diamonds and indicator minerals could grow. This is why so long a list of low-temperature mineral inclusions, such as quartz, feldspar, amphibole, biotite, staurolite, serpentine, carbonate, has been found in diamonds.

Kimberlite pipe formation by water-hammer mechanism can explain the existence of so-called "blind" pipes, which never reached the land surface. 
One of the most important conclusions of the theory of liquid immiscibility of kimberlite magma is one-act eruption of magma in the cavity of each compound-built pipe, and, possibly, several closely located pipes.

\section{References:}

Anikin, I.N. , 1977, The main peculiarities of a mica (phlogopite) crystallization from the melt: The Growth of Crystals, \# 12

Tamman, G, 1935, The handbook for heterogeneous equilibriums, L., ONTI Ilupin, I.P., Kaminsky, F.V., Frantsesson, E.V., 1978, The geochemistry of kimberlites, M., Nedra.

1.

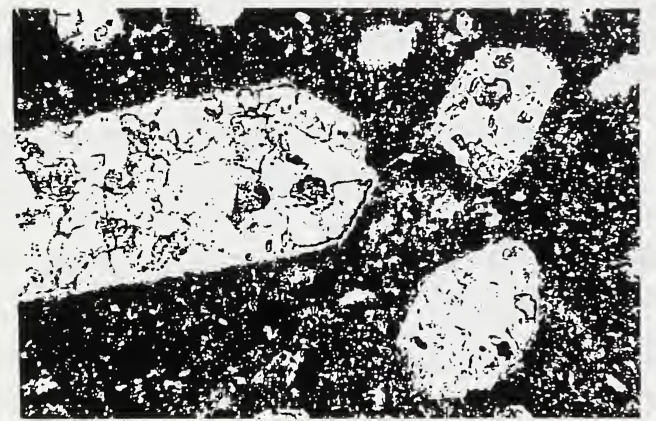

3.

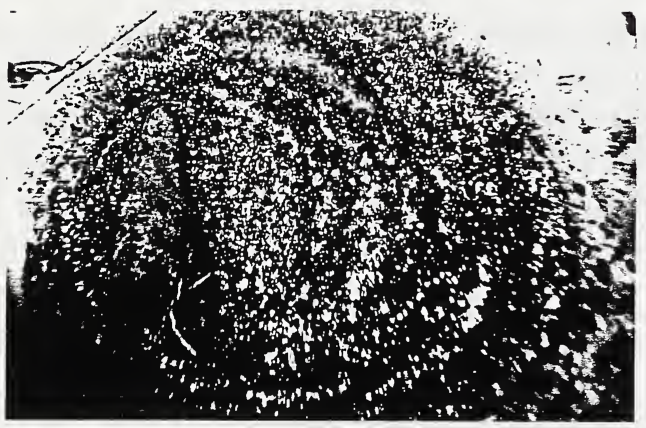

5.

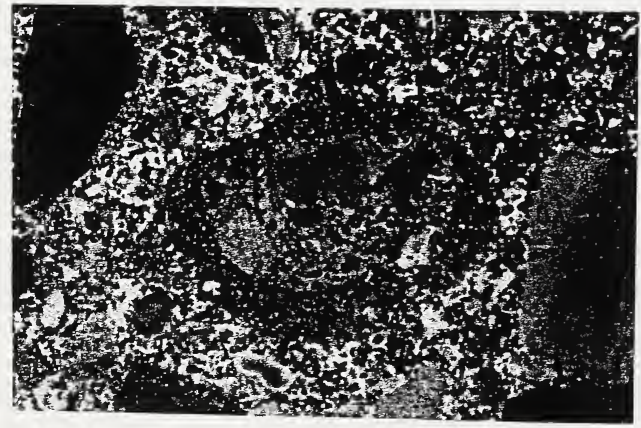

2.
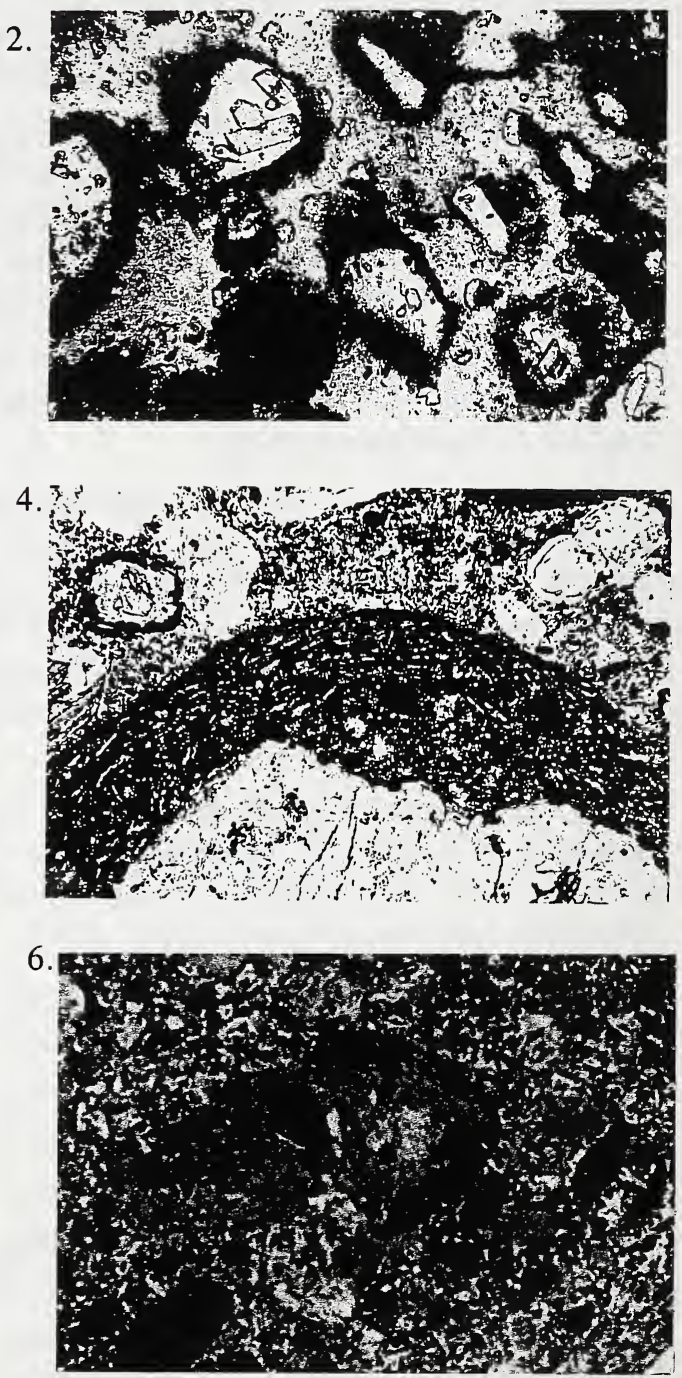